\title{
Child Labour Ethics through the Prism of Utilitarianism and Deontology
}

\author{
Krummel Daniel1, Siegfried Patrick ${ }^{2}$ \\ ${ }^{1}$ International Business and Management, Alliance Manchester Business School, Manchester, UK \\ ${ }^{2}$ International Management, Logistics \& Supply Chain Management, International School of Management, Frankfurt, Germany \\ Email: daniel.krummel@yahoo.de
}

How to cite this paper: Daniel, K. and Patrick, S. (2021) Child Labour Ethics through the Prism of Utilitarianism and Deontology. Open Access Library Journal, 8: e7140. https://doi.org/10.4236/oalib.1107140

Received: January 9, 2021

Accepted: February 6, 2021

Published: February 9, 2021

Copyright (C) 2021 by author(s) and Open Access Library Inc.

This work is licensed under the Creative Commons Attribution International License (CC BY 4.0).

http://creativecommons.org/licenses/by/4.0/ (c) (i) Open Access

\begin{abstract}
Purpose: Grounded in the theoretical concepts of utilitarianism and deontology, this paper aims to evaluate the issue of child labour from an ethics perspective. By linking utilitarianism with normative stakeholder theory, relevant stakeholder groups are being identified in order to examine their influence on and role in the occurrence of child labour allowing for a practical reference. The findings may serve companies in particular as a basis for decision-making in the development of their value chains. Design/Methodology/Approach: The author uses a literature review in order to analyze the findings of existing literature on the topic of child labour in an ethics context, thereby drawing on literature, indexed in Web of Science and Google Scholar by employing forward and backward citation analysis. Findings: The investigation of child labour in terms of ethics yields conflicting results. From a deontological perspective, child labour can never be ethical and should always be rejected as it is not wanted to become a general law. In contrast, according to a utilitarian sentiment, child labour is ethically justifiable as long as the beneficiaries of the labour are greater in number than the children working or suffering. Originality/Value: The examination of child labour from the perspective of deontology and utilitarianism in conjunction with normative stakeholder theory constitutes a novelty in the ethics literature. The integration of theoretical findings into a practical business context provides additional value for managers and global supply chain managers.
\end{abstract}

\section{Subject Areas}

Business Ethics and Corporate Social Responsibility

\section{Keywords}

Child Labour, Deontology, Utilitarianism, Ethics 


\section{Introduction}

"There can be no keener revelation of a society's soul than the way in which it treats its children [emphasis added]." Nelson Mandela

(Blanchett and Shealey, 2013, p. 1) [1]

In 2018, Germany, Canada, Australia and Denmark accounted for a total population of approximately 152 million people (The World Bank, 2018) [2]. Alas, this corresponds to ILO (2017) [3] estimates about the number of children engaged in CL worldwide of which 73 million are exposed to hazardous working conditions (UN, 2019) [4]. A total, that has declined by $10 \%$ in a period of a mere four years since 2012 (167.9 million) (ILO, 2017) [3]. Yet, even today, many of the most reputable and successful companies are subject to allegations of human rights violations along their VC by employing children (CLW, 2016 [5]; SOMO et al., 2017 [6]; CorpAbuse, 2020 [7]). The CLC is additionally "concerned that the pace of ending CL has slowed decidedly" (Maki, 2017) [8]. As CL being widely prohibited and morally condemned in Western economies (Pierik, 2007) [9], such violations are occurring almost invariably at the lower end of VCs in developing countries (ILO, 2017a) [10]. Kant would indeed support this Western sentiment, since the worst forms of CL inherently violate the child's autonomy (Radfar et al., 2018) [11]. Yet, the ethical dilemma of CL is revealed by the perspective of corresponding stakeholders in the light of the universalism theory (Meiklejohn, 1998) [12], providing rationale favouring CL in contrast (Hindman and Smith, 1999 [13]; Radfar et al., 2018 [11]).

Tersely said, the remainder of this essay is devoted to assessing the ethics of CL by, inter alia, identifying relevant stakeholders and the implications of CL on them. The findings might serve companies as decision basis for their VC creation.

\section{Child Labour: Background}

The kind of labour that this essay focuses on is regarded "as work that deprives children of their childhood, their potential and their dignity, and that is harmful to physical and mental development" (ILO, 2004, p. 16) [14], which also eliminates their opportunities for proper education (Amnesty International, 2017) [15]. Correspondingly, Figure 1 encapsulates a general outline of global CL facts. The ILO indicates that child labour is a global phenomenon, yet primarily occurs in the agricultural sector of economically weak regions in global terms. Africa is thus be found constituting the lion's share of $19.6 \%$ of the world's 153 million children being employed in forced labour. Almost every second child is aged 5 - 11.

Despite the suffering inflicted on many children by labour, some voices favour CL by referring their moral justification to the impoverished conditions from which it originates (Lund-Thomsen, 2008 [16]; Radfar et al., 2018 [11]). Basically, socio-economic and cultural disparities are a significant determinant of the defined nature of CL (Blanchett and Shealey, 2013) [1], being responsible for the 


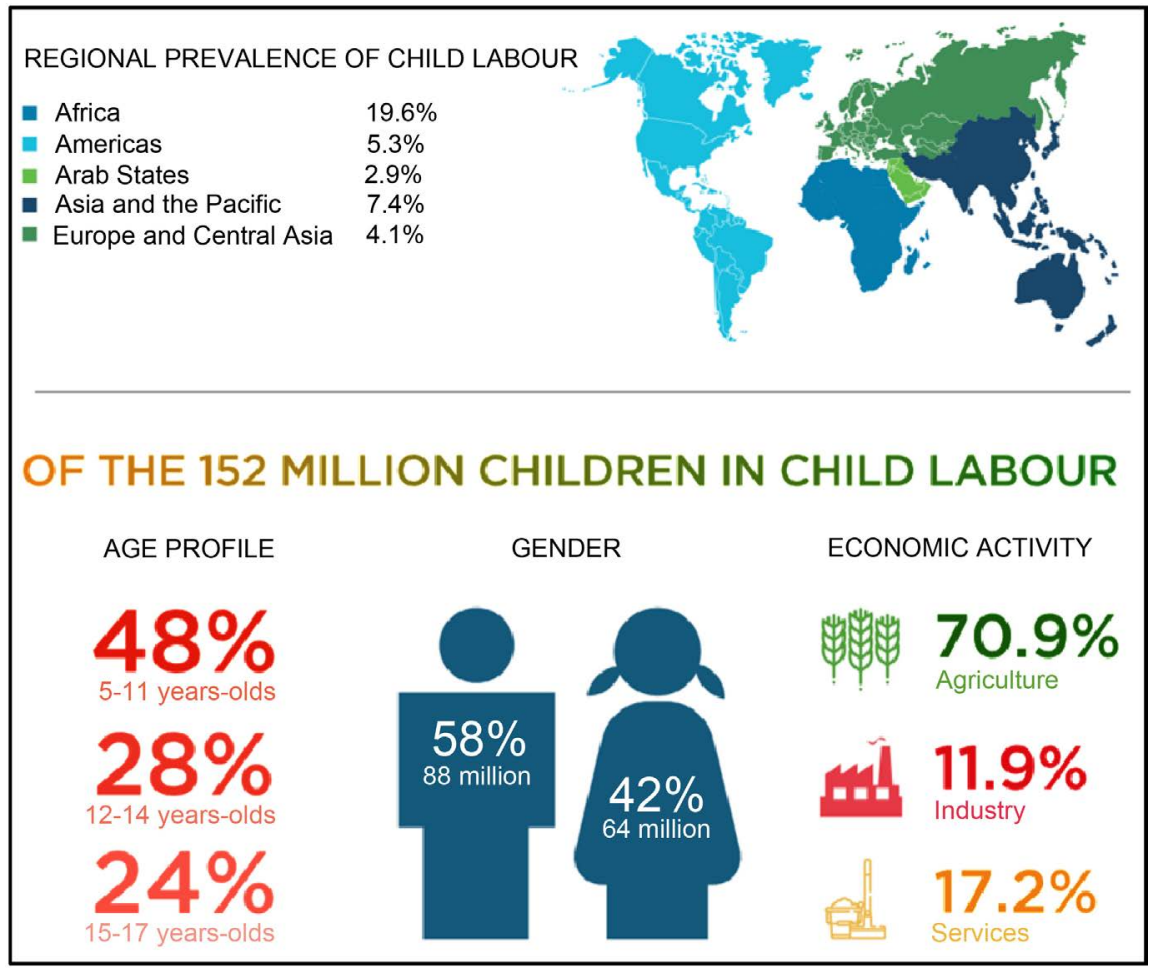

Figure 1. CL key facts (ILO, 2017) [3].

divergent distribution and perception of CL globally. In consent, Pierik (2007) [9] expounds by referring to culturally diverse concepts of childhood. Consequently, in the absence of alternatives many developing countries perceive the employment of children as means to provide for a family's livelihood (Basu, 2003 [17]; Chamarbagwala, 2008 [18]).

Basically, the ILO (2017a) [10] in accordance with UNCRC (1989) [19] holds

- poverty and the absence of social welfare systems.

- lack of legal protection due to weak institutional frame.

- limited education access.

- absence of decent work opportunities.

To be the main factors contributing to CL, predominantly present in developing countries. The different moral concepts regarding CL make it particularly difficult to effectively impose Western morals (Wiredu, 2008) [20]. See Annex A for additional comments of a rights perspective on CL.

\section{Child Labour: An Ethical Assesment}

This work is based on the application of two ethical theories, deontology and utilitarianism theory, to evaluate CL from an ethics perspective. Table 1 allows a preliminary overview of both concepts.

The two theories differ fundamentally in their focus. While deontology is concerned with the intrinsic nature of a specific matter whether or not wanted to be a general state, utilitarianism, independent of a matter's nature, is concerned with the weighing of utility and expense. A more detailed outline of both ethical 
Table 1. Deontology vs. utilitarianism, own table, based on Gray and Schein (2012) [21]; Gawronski and Beer (2016) [22].

\begin{tabular}{lll}
\hline \multicolumn{1}{c}{ Deontology } & \multicolumn{1}{c}{ Utilitarianism } \\
\hline Supreme principle of morality & $\begin{array}{l}\text { Categorical imperative } \\
\text { Actions or norms are judged to } \\
\text { Object of moral assessment }\end{array}$ & $\begin{array}{l}\text { Utilitarianism } \\
\text { Actions are judged by their } \\
\text { their attributes } \\
\text { consequences } \rightarrow \text { "the ends } \\
\text { justify the means" }\end{array}$ \\
Assessment process & $\begin{array}{l}\text { Generalisability of the action } \\
\text { maxim }\end{array}$ & Cost-benefit analysis \\
Ethics & Deontological & Teleological \\
\hline
\end{tabular}

approaches is given below.

\subsection{Deontological Perspective}

Deontological ethics, also known as universalism, is a branch of ethical theories that determines the moral and status of an action not by its consequences, yet rather by principles such as justice, rights or fairness, and is therefore considered to contrast the consequentialist theory (Weiss, 2014) [23]. This dichotomy is likewise the rationale behind the choice of these two theories to enrich the significance of the results by additionally including an important corrective for the quantifying cost-benefit balance of a utilitarian ethic (Van Staveren, 2007) [24].

Kant, being considered one of the fathers of universalism (Marques, 2015) [25], holds the categorical imperative as the fundamental principle and moral law of ethical behaviour (Höffe, 1977) [26]. This concept consists of three formulas, which are elaborated below.

Firstly, the ethics of an action is based on the question whether it follows a maxim whose validity would be acceptable to all individuals, at any time and without exception, from which, at the same time, you would want it to become a general law (The Universal Law of Nature Formula) (Von Ebert, 1976) [27]; Korsgaard, 1985 [28]). Accordingly, the likelihood of CL becoming a universal law whose disregard would be considered immoral is extremely remote. Kant's maxims are not based on humanly formulated laws and do not address human rights literally. However, concepts such as dignity, freedom, wellbeing and autonomy are central to both (Van Staveren, 2007) [24]. The corresponding violation of the fundamental human rights of children conflicts with the idea of social welfare, since many types of CL cause permanent damage to body and mind, preventing most child workers from reaching the age of 50 (Radfar et al., 2018) [11].

Secondly, all individuals affected should not be treated as mere means to another end, but rather as an end in itself, i.e. they must not be threatened in their freedom and dignity (The Humanity Formula) (Sullivan, 1997) [29]. As a matter of fact, the employment of children is about the instrumental use of cheap labour and not for the end in itself or the establishment of dignity, rather 
the opposite. Additionally, beating, humiliating and psychological assault of children is opposed to any humanitarian standpoint (Kreikebaum, 2006 [30]; Amnesty International, 2018 [31]).

Thirdly, Kant continues that each subject, through his own use of reason, must establish maxims of will that have the form of universality but do not interfere with the freedom of others (The Autonomy Formula) (Reath, 1994) [32]. Here, individuals are law-givers instead of followers of the universal law as indicated in the first formula (Reath, 1989) [33]. At this point the question has to be raised from which age on children is able to assess their situation correctly and to distinguish right from wrong. Meaning, from when on, are children able to develop reasons and make decisions autonomously from their parents (Yovel, 1998) [34]? However, children must be free to decide whether they want to work or not in order to allow ethical vindication. If they are voluntarily willing to work for the benefit of the family, this would be ethically acceptable according to Kant (Kreikebaum, 2006) [30]. Resulting from their age, however, they are dependent on their parents, which limit the child's autonomy. Accordingly, the lack of alternatives, such as education, and poverty of the family drives parents to send children to work (Pierik, 2007) [9]. Since this taking up of work is not determined by the child itself rather directed by other parties, CL thus, likewise regarding the first two formulas, appears to be utterly immoral viewed from the vantage point of Kant's three formulas of the categorical imperative.

However, this theory also bears some drawbacks. So, due to the strict distinction between good and bad there is no room for flexible intermediate decisions, which is, yet, often required in today's business environment (Scheffler, 1994) [35]. For instance, despite the rejection by the categorical imperative, CL offers benefits to some stakeholders (Marques, 2015) [25].

\subsection{Stakeholder in a Utilitarianism Context}

The author endeavours to open up the subject of CL for executives by linking normative stakeholder theory and utilitarianism. Accordingly, classical utilitarianism is a hedonistic concept which assumes that there are measurable amounts of joy and pain. Utilitarianism ${ }^{1}$ takes the view that an action is ethically justifiable if the output is greater than the pain for all concerned (Posner, 1979) [36]. Utilitarianism can be assigned to the theories of consequentialism, according to which the moral correctness of an action depends solely on the actual consequences of that action (Sinnott-Armstrong, 2014) [37]. Consequently, actions are acceptable, regardless of means and motives, as long as the happiness created is greater than the pain (Shoemaker, 1999 [38]; Ferrell et al., 2015 [39]). Also, in a utilitarian analysis all interest groups are regarded equally, i.e. no stakeholder is assigned more or less importance (Weiss, 2014) [23].

MNEs have certain responsibilities towards those who may be affected by its

${ }^{1}$ The first proponents of the utilitarian theory include Hume (17402000), Bentham (17891996) and Mill (18631998). 
activities (Freeman, 1984) [40], such as employees, shareholders and customers (Chen and Roberts, 2010 [41], Siegfried 2015a [42]). Satisfying stakeholder needs goes beyond mere profit maximisation and requires understanding stakeholder demands. As CL is a morally controversial issue, the normative stakeholder approach of Donaldson and Preston (1995) [43] will be applied in the following, as the relationship between the company and its stakeholders is based on moral and normative obligations. Ergo, business decisions should be predicated on ethical considerations, as such behaviour is not only appropriate but also desired by stakeholders (Ibid.).

Hereinafter, six stakeholders mostly affected by CL are examined in a "cost-benefit" calculus (Greene et al., 2008) [44], as already alluded in Table 2 ex ante, to reach clarity about the moral status of CL.

According to Manda et al. (2003) [45], work can contribute to children's development and parents' pride in seeing children following their footsteps and by taking part in a broader socialisation processes (Potter and Lupilya, 2016) [46]. Additionally, CL often times seems to be the best alternative under given circumstances. Yet in their work, these children are often exposed to physical or verbal violence (Harari et al., 1997) [47], hazardous substances (chemicals and pesticides) (Wilk, 1993) [48], and deprivation of freedom, frequently causing permanent health damage or even death (Morris, 2010) [49].

Notwithstanding, CL provides impoverished families a vital source of income (Shumetie and Mamo, 2019) [50]. Simultaneously, since the work occupies the entire time, children often are unable to receive basic education (Quattri and Watkins, 2019) [51]. A deficit, that leads to high opportunity costs accounting to an $11 \%$ loss of income per missed school year (UNICEF, 2004) [52], which will deprive the family of higher long-term earnings. Beyond that, as being aware of the terrible working conditions their children are exposed to, parents are most likely plagued by accusations and pity (Pierik, 2007) [9].

Furthermore, shareholders are benefitting from $\mathrm{CL}$ in form of higher ROI since production is carried out at low wage costs, the expenditure is thus lower which in turn results in a higher yield (Manda et al., 2003 [45]; Sprinkle and Maines, 2010 [53]). Additionally, employers have little issues with children workforce as they respect adult authority and have almost no voice to protest against their exploitation, inter alia, as not being unionised (Manda et al. 2003 [45], Siegfried 2015b [54]). However, CL might have a negative impact on a company's image, which is likely to cause the opposite situation. In accordance, many studies show that being responsible, e.g. by avoiding CL in the VC, reputation can be increased and may thereby additionally attract CSR conscious shareholders (Cheng et al., 2014 [55]; Hart and Zingales, 2017 [56]), leading to long-term profitability as well as competitive edge (Vogel, 2005 [57]; Carroll and Shabana, 2010 [58]). In either case, to capitalise on CSR, initiatives must be specifically aligned with the desires of shareholders and stakeholders (McWilliams and Siegel, 2001) [59].

Moreover, CL enables customers all over the world to buy low-price products 
Table 2. Potential effects of CL on stakeholder groups, own table.

\begin{tabular}{|c|c|c|c|}
\hline \multirow{2}{*}{ STAKEHOLDER } & \multicolumn{2}{|c|}{ GENERAL EVALUATION } & \multirow{2}{*}{ PSYCHOLOGICAL EVALUATION } \\
\hline & Unfavourable (costs) & Favourable (benefits) & \\
\hline \multirow{7}{*}{ Children } & $\begin{array}{l}\text { Deprives opportunities for } \\
\text { education }\end{array}$ & $\begin{array}{l}\text { Following footsteps of parents } \\
\text { leading towards socialisation and } \\
\text { personal development }\end{array}$ & $\begin{array}{l}\text { Lack of education inhibits psychological } \\
\text { maturity }\end{array}$ \\
\hline & $\begin{array}{l}\text { Health Problems (e.g. breathing } \\
\text { problems, chest pains, skin } \\
\text { infections, bone deformation) }\end{array}$ & $\begin{array}{l}\text { CL as best among given } \\
\text { alternatives (see prostitution) } \\
\text { since lack of options }\end{array}$ & \multirow[t]{6}{*}{ Escape family violence } \\
\hline & Little or no payment & $\begin{array}{l}\text { Contributions of children's } \\
\text { earnings to household income } \\
\text { (pride) }\end{array}$ & \\
\hline & $\begin{array}{l}\text { Physical/psychological/sexual } \\
\text { abuse }\end{array}$ & \multirow[t]{4}{*}{$\begin{array}{l}\text { Some employers provide meals } \\
\text { and accommodation }\end{array}$} & \\
\hline & $\begin{array}{l}\text { Hazardous working environment } \\
\text { (e.g. materials such as pesticides) }\end{array}$ & & \\
\hline & Malnutrition & & \\
\hline & $\begin{array}{l}\text { Long working hours or } \\
\text { slave-like employment }\end{array}$ & & \\
\hline Families & $\begin{array}{l}\text { Child labour deprives children } \\
\text { (and families) of the opportunity } \\
\text { for education thus prevents } \\
\text { opportunities for higher } \\
\text { long-term income }\end{array}$ & CL provides livelihood & $\begin{array}{l}\text { Pity and fear for children, don't want them } \\
\text { to be treated badly or in danger }\end{array}$ \\
\hline Investors & Lower long-term profits & higher short-term profits & $\begin{array}{l}\text { Reputation Dilemma (negative image } \\
\text { might reduce sharholder value) }\end{array}$ \\
\hline Customers & & $\begin{array}{l}\text { CL enables consumers to } \\
\text { buy goods cheaply (low } \\
\text { price products) }\end{array}$ & $\begin{array}{l}\text { Ethical Dilemma (support CL through } \\
\text { buying cheap products) }\end{array}$ \\
\hline \multirow{2}{*}{$\begin{array}{l}\text { Governments (of } \\
\text { country where CL } \\
\text { takes place) }\end{array}$} & $\begin{array}{l}\text { Child labour discourages FDI } \\
\text { resulting in lower tax revenues }\end{array}$ & $\begin{array}{l}\text { Low labour costs attracting FDI } \\
\text { leading to higher tax revenues }\end{array}$ & \multirow[t]{2}{*}{ Reputation Dilemma } \\
\hline & $\begin{array}{l}\text { Increase in adult unemployment } \\
\text { rate due to rock-bottom wages of } \\
\text { children }\end{array}$ & & \\
\hline \multirow[b]{2}{*}{ Companies } & $\begin{array}{l}\text { Decline in revenue resulting from } \\
\text { boycott of child labour products }\end{array}$ & $\begin{array}{l}\text { Cutting costs by outsourcing and } \\
\text { capitalising on CL }\end{array}$ & \multirow[t]{2}{*}{ Ethical Dilemma } \\
\hline & $\begin{array}{l}\text { Inexperience of children may } \\
\text { bear losses }\end{array}$ & $\begin{array}{l}\text { Low resistance, given that } \\
\text { children have weak voice } \\
\text { rights and no unions }\end{array}$ & \\
\hline
\end{tabular}

(Weiss, 2014) [23]. Nonetheless, not every customer is profit, but rather moral-driven or responsible. To this end, revelations about products produced by children often lead to boycotts of these (Ballet et al., 2014) [60].

Beyond that, the reputation of a low-wage country has the potential to attract much foreign investment, which can bring governments higher tax revenues (Donaubauer and Dreger, 2018) [61]. Yet, the ground for this condition may al- 
so have the opposite effect. Lastly, many developing economies or governments are unable to compensate for the lack of cheap CL, as the wages for adult workers are considerably higher. This might also increase the unemployment rate among adults, as more importance is attached to children (Abe and Ogawa, 2017 [62]; Chakraborty and Chakraborty, 2018 [63]).

Since the action scope of managers is constrained by bounded moral rationality like laws and contracts, the ability to pursue the maxim of the greatest benefit is considerably reduced, which renders the application benefit of this theory in a business context rather detrimental (Donaldson and Dunfee, 1995 [64], Siegfried $2011[65])$.

\section{Conclusions}

This essay aimed to examine the issue of CL from the perspective of the two ethical theories of deontology and utilitarianism which were correspondingly employed as a basis for assessment and might serve companies in structuring their GVC. In compliance with Kant, companies should only tolerate CL in their GVC if they want it to become a general law. Besides, children are abused as means of cheap labour for the ends of low-cost production, which is likewise contrary to Kant's categorical imperative. CL additionally restricts the child's autonomy, which in many circumstances causes physical and psychological abuse rendering this concept intrinsic bad, thus unethical from a deontological point of view. Utilitarianism, on the other hand, does not provide a general assessment as being largely dependent on the comparative value or level of comparison (e.g. family) that is placed against CL. Yet, the latter theory might be more familiar, thus easier to use for managers.

Although the concept of the greater good is generally appealing, the author's background shapes his judgment in the light of European values. The exploitative employment of children does not correspond to German ideas of a typical and appropriate childhood and is accordingly never considered desirable as a state to be aspired equally for all children. Accordingly, the author concludes, in the spirit of deontology, that child labour is morally indefensible. However, it should be noted that an assessment of the child labour issue from a given distance is rather intricate thus not completely appropriate as it is much more complex under other than European/German circumstances. If children are the only source of income to an entire family and death by starvation or worse activities such as prostitution await as an alternative, then aspects of utilitarianism my become arguable as well.

\section{Limitations and Future Research Directions}

As the time frame within which this paper was developed has been very limited due to tight deadlines, it may well be that the existing literature or previous studies have not been sufficiently analysed in this context. Future researchers examining the moral evaluation of child labour from the perspective of deontol- 
ogy and utilitarianism should conduct their literature review to a more extensive degree by exploring additional literature databases.

As this work is based exclusively on secondary literature, a lack of empirical data is evident. An empirical investigation through e.g. expert interviews in order to obtain expert opinions on this topic would certainly be insightful and would provide future researchers with new avenues of research.

By interviewing various populations of different countries, it might be possible to determine different perceptions of child labour that exist. A differing definition of child labour and customs, which generally regard the employment of children as an essential step in childhood, would not be compatible with the definition of deontology given in this paper. A fact calls for further research.

Future researchers may also wish to examine and compare legal perspectives on child labour in different regions/countries in order to draw conclusions about possible variations in moral perceptions.

\section{Conflicts of Interest}

The authors declare no conflicts of interest regarding the publication of this paper.

\section{References}

[1] Blanchett, W.J. and Shealey, M.W. (2013) Responding to the Needs of Ethnically and Culturally Diverse Learners with Exceptionalities and Their Families. Multiple Voices for Ethnically Diverse Exceptional Learners, 13, 1-3.

[2] The World Bank (2018) Population, Worldwide. Data. https://data.worldbank.org/indicator/SP.POP.TOTL

[3] ILO (2017) Ending Child Labour by 2025: A Review of Policies and Programmes.

[4] UN (2019) World Day against Child Labour, 12 June. https://www.un.org/en/events/childlabourday/background.shtml

[5] CLW (2016) Working 10 Hours Every Day, a 14 Year Old Child Worker from Foshan Dies from Exhaustion. http://www.chinalaborwatch.org/newscast/596

[6] SOMO, ALR and LRDP (2017) The Myanmar Dilemma: Can the Garment Industry Deliver Decent Jobs for Workers in Myanmar?

[7] CorpAbuse (2020) Companies-CorpAbuse. https://corpabuse.org/companies/?filter type=global-brands

[8] Maki, R. (2017) Child Labour Coalition Statement on New Estimates of Child Labor. Stopchildlabor. http://stopchildlabor.org/? $\mathrm{p}=4443$

[9] Pierik, R. (2007) Fighting Child Labor Abroad: Conceptual Problems and Practical Solutions. In: Gehrig, V., Ed., The Ethical Dimensions of Global Development, Rowman \& Littlefield Publishers, Lanham, 47-57.

[10] ILO (2017) Global Estimates of Child Labour: Results and Trends, 2012-2016. https://www.ilo.org/wcmsp5/groups/public/@dgreports/@dcomm/documents/publi cation/wcms 575499.pdf

[11] Radfar, A., Asgharzadeh, S.A., Quesada, F. and Filip, I. (2018) Challenges and Perspectives of Child Labor. Industrial Psychiatry Journal, 27, 17-20.

https://doi.org/10.4103/ipj.ipj_105_14 
[12] Meiklejohn, D. (1998) Child Labour. Ethical Consumer No. 51, 30.

[13] Hindman, H.D. and Smith, C.G. (1999) Cross-Cultural Ethics and the Child Labor Problem. Journal of Business Ethics, 19, 21-33. https://doi.org/10.1023/A:1006193721017

[14] ILO (2004) Child Labour: A Textbook for University Students. International Labour Office, Geneva.

[15] Amnesty International (2017) Time to Recharge: Corporate Action and Inaction to Tackle Abuses in the Cobalt Supply Chain. https://www.amnesty.org/download/Documents/AFR6273952017ENGLISH.PDF

[16] Lund-Thomsen, P. (2008) The Global Sourcing and Codes of Conduct Debate: Five Myths and Five Recommendations. Development and Change, 39, 1005-1018. https://doi.org/10.1111/j.1467-7660.2008.00526.x

[17] Basu, K. (2003) The Global Child Labor Problem: What Do We Know and What Can We Do? The World Bank Economic Review, 17, 147-173. https://doi.org/10.1093/wber/lhg021

[18] Chamarbagwala, R. (2008) Regional Returns to Education, Child Labour and Schooling in India. The Journal of Development Studies, 44, 233-257. https://doi.org/10.1080/00220380701789935

[19] UNCRC (1989) The United Nations Convention on the Rights of the Child. Unicef UK.

https://downloads.unicef.org.uk/wp-content/uploads/2016/08/unicef-convention-ri ghts-child-uncrc.pdf? ga=2.123746762.1370693363.1588103156-190427524.158810 $\underline{3156}$

[20] Wiredu, K. (2008) Social Philosophy in Postcolonial Africa: Some Preliminaries Concerning Communalism and Communitarianism. South African Journal of Philosophy, 27, 332-339. https://doi.org/10.4314/sajpem.v27i4.31522

[21] Gray, K. and Schein, C. (2012) Two Minds vs. Two Philosophies: Mind Perception Defines Morality and Dissolves the Debate between Deontology and Utilitarianism. Review of Philosophy and Psychology, 3, 405-423. https://doi.org/10.1007/s13164-012-0112-5

[22] Gawronski, B. and Beer, J.S. (2016) What Makes Moral Dilemma Judgments "Utilitarian" or "Deontological"? Social Neuroscience, 12, 626-632. https://doi.org/10.1080/17470919.2016.1248787

[23] Weiss, J. (2014) Business Ethics. 6th Edition, Berrett-Koehler Publishers, Oakland.

[24] Van Staveren, I. (2007) Beyond Utilitarianism and Deontology: Ethics in Economics. Review of Political Economy, 19, 21-35. https://doi.org/10.1080/09538250601080776

[25] Marques, J. (2015) Universalism and Utilitarianism: An Evaluation of Two Popular Moral Theories in Business Decision Making. The Journal of Values-Based Leadership, 8, Article 3.

[26] Höffe, O. (1977) Kants kategorischer Imperativ als Kriterium des Sittlichen. Zeitschrift für philosophische Forschung, 31, 354-384.

[27] Von Ebert, T. (1976) Kants kategorischer Imperativ und die Kriterien gebotener, verbotener und freigestellter Handlungen. Kant-Studien, 67.

https://www.degruyter.com/view/j/kant.1976.67.issue-1-4/kant.1976.67.1-4.570/kan $\underline{\mathrm{t} .1976 .67 .1-4.570 . \mathrm{xml}}$

[28] Korsgaard, C.M. (1985) Kant's Formula of Universal Law. Pacific Philosophical Quarterly, 66, 24-47. https://dash.harvard.edu/handle/1/3201869 
[29] Sullivan, R.J. (1997) An Introduction to Kant's Ethics. Cambridge University Press, Cambridge.

[30] Kreikebaum, H. (2006) Internationale Unternehmensethik. In: Albach, H., Ed., Unternehmensethik und globale Märkte. Zeitschrift für Betriebswirtschaft Special issue, Gabler, Wiesbaden.

[31] Amnesty International (2018) Amnesty International Report 2017/2018-The State of the Worlds Human Rights.

[32] Reath, A. (1994) Legislating the Moral Law. Noûs, 28, 435-464. https://doi.org/10.2307/2215474

[33] Reath, A. (1989) The Categorical Imperative and Kant's Conception of Practical Rationality. The Monist, 72, 384-410. https://doi.org/10.5840/monist198972322

[34] Yovel, Y. (1998) Kant's Practical Reason as Will: Interest, Recognition, Judgment, and Choice. The Review of Metaphysics, 52, 267-294.

[35] Scheffler, S. (1994) The Rejection of Consequentialism. Oxford University Press, Oxford. https://doi.org/10.1093/0198235119.001.0001

[36] Posner, R.A. (1979) Utilitarianism, Economics, and Legal Theory. The Journal of Legal Studies, 8, 103-140. https://doi.org/10.1086/467603

[37] Sinnott-Armstrong, W. (2014) Consequentialism. In: Zalta, E.N., Ed., The Stanford Encyclopedia of Philosophy, Springer, Berlin.

[38] Shoemaker, D.W. (1999) Utilitarianism and Personal Identity. The Journal of Value Inquiry, 33, 183-199. https://doi.org/10.1023/A:1004400627563

[39] Ferrell, O.C., Fraedrich, J. and Ferrell, L. (2015) Business Ethics: Ethical Decision Making and Cases. 10th Edition, Cengage Learning, Stamford.

[40] Freeman, R.E. (1984) Strategic Management: A Stakeholder Perspective. Pitman, Boston.

[41] Chen, J.C. and Roberts, R.W. (2010) Toward a More Coherent Understanding of the Organization-Society Relationship: A Theoretical Consideration for Social and Environmental Accounting Research. Journal of Business Ethics, 97, 651-665. https://doi.org/10.1007/s10551-010-0531-0

[42] Siegfried, P. (2015) Business Ethics, Sustainability and CSR. Volume 1, AVM Akademische Verlagsgemeinschaft, München, 135.

[43] Donaldson, T. and Preston, L.E. (1995) The Stakeholder Theory of the Corporation: Concepts, Evidence, and Implications. The Academy of Management Review, 20, 65-91. https://doi.org/10.2307/258887

[44] Greene, J.D., et al. (2008) Cognitive Load Selectively Interferes with Utilitarian Moral Judgment. Cognition, 107, 1144-1154. https://doi.org/10.1016/j.cognition.2007.11.004

[45] Manda, D.K., Kimalu, P.K., Nafula, N.N., Kimani, D.N., Nyaga, R.K., Mutua, J.M., Mwabu, G. and Kimenyi, M.S. (2003) Costs and Benefits of Eliminating Child Labour in Kenya. Kenya Institute for Public Policy Research and Analysis, Nairobi.

[46] Potter, C. and Lupilya, A.C. (2016) "You Have Hands, Make Use of Them!” Child Labour in Artisanal and Small-Scale Mining in Tanzania. Journal of International Development, 28, 1013-1028. https://doi.org/10.1002/jid.3245

[47] Harari, R., Forastiere, F. and Axelson, O. (1997) Unacceptable "Occupational” Exposure to Toxic Agents among Children in Ecuador. American Journal of Industrial Medicine, 23, 185-190. https://doi.org/10.1002/(SICI)1097-0274(199709)32:3<185::AID-AJIM1>3.0.CO;2- 
$\underline{\mathrm{X}}$

[48] Wilk, V.A. (1993) Health Hazards to Children in Agriculture. American Journal of Industrial Medicine, 24, 283-290. https://doi.org/10.1002/ajim.4700240305

[49] Morris, R.C. (2010) Can the Subaltern Speak? Reflections on the History of an Idea. Columbia University Press, New York.

[50] Shumetie, A. and Mamo, K. (2019) Effect of Cropland and Livestock Ownership on Child Labour in Eastern Ethiopia: Empirical Examination of the Wealth Paradox. International Journal of Child Care and Education Policy, 13, Article 5. https://doi.org/10.1186/s40723-019-0061-x

[51] Quattri, M. and Watkins, K. (2019) Child Labour and Education-A Survey of Slum Settlements in Dhaka (Bangladesh). World Development Perspectives, 13, 50-66. https://doi.org/10.1016/j.wdp.2019.02.005

[52] UNICEF (2004) Eliminating Child Labour: The Costs and Benefits. http://www.ilo.org/global/about-the-ilo/newsroom/news/WCMS 075570/lang--en/i ndex.htm

[53] Sprinkle, G. and Maines, L. (2010) The Benefits and Costs of Corporate Social Responsibility. Business Horizons, 53, 445-453. https://doi.org/10.1016/j.bushor.2010.05.006

[54] Siegfried, P. (2015) Business Ethics, Sustainability and CSR. Volume 2, AVM Akademische Verlagsgemeinschaft, München, 87.

[55] Cheng, B., Ioannou, I. and Serafeim, G. (2014) Corporate Social Responsibility and Access to Finance. Strategic Management Journal, 35, 1-23. https://doi.org/10.1002/smj.2131

[56] Hart, O. and Zingales, L. (2017) Companies Should Maximize Shareholder Welfare Not Market Value. Journal of Law, Finance, and Accounting, 2, 247-275. https://doi.org/10.1561/108.00000022

[57] Vogel, D.J. (2005) Is There a Market for Virtue? The Business Case for Corporate Social Responsibility. California Management Review, 47, 19-45. https://doi.org/10.2307/41166315

[58] Carroll, A.B. and Shabana, K.M. (2010) The Business Case for Corporate Social Responsibility: A Review of Concepts, Research and Practice. International Journal of Management Reviews, 12, 85-105. https://doi.org/10.1111/j.1468-2370.2009.00275.x

[59] McWilliams, A. and Siegel, D. (2001) Corporate Social Responsibility: A Theory of the Firm Perspective. Academy of Management Review, 26, 117-127. https://doi.org/10.5465/amr.2001.4011987

[60] Ballet, J., Bhukuth, A. and Carimentrand, A. (2014) Child Labor and Responsible Consumers: From Boycotts to Social Labels, Illustrated by the Indian Hand-Knotted Carpet Industry. Business \& Society, 53, 71-104.

https://doi.org/10.1177/0007650311416070

[61] Donaubauer, J. and Dreger, C. (2018) The End of Cheap Labor: Are Foreign Investors Leaving China? Asian Economic Papers, 17, 94-107. https://doi.org/10.1162/asep a 00611

[62] Abe, K. and Ogawa, H. (2017) Globalization, Child Labour and Adult Unemployment. The Ritsumeikan Economic Review, 65, 193-205.

[63] Chakraborty, K. and Chakraborty, B. (2018) Low Level Equilibrium Trap, Unemployment, Efficiency of Education System, Child Labour and Human Capital Formation. Journal of Economics, 125, 69-95.

https://doi.org/10.1007/s00712-017-0585-x 
[64] Donaldson, T. and Dunfee, T.W. (1995) Integrative Social Contracts Theory: A Communitarian Conception of Economic Ethics. Economics and Philosophy, 11, 85-112. https://doi.org/10.1017/S0266267100003230

[65] Siegfried, P. (2011) Die Bedeutung des Ethischen für den ökonomischen Prozess. AVM Akademische Verlagsgemeinschaft, München, 100.

[66] The World Counts (2020) Global Challenges. https://www.theworldcounts.com/challenges

[67] UNICEF (2014) Child Labour and UNICEF in Action: Children at the Centre.

[68] ILAB (2018) Findings on the Worst Forms of Child Labor-Colombia. U.S. Department of Labor, Washington DC.

https://www.dol.gov/agencies/ilab/resources/reports/child-labor/colombia

[69] Amnesty International (2016) “This Is What We Die for" Human Rights Abuses in the Democratic Republic of the Congo Power the Global Trade in Cobalt. https://www.amnesty.org/download/Documents/AFR6231832016ENGLISH.PDF 


\section{Annex: A Brief Rights Perspective on Child Labour}

$10 \%$ of the world's child population is affected by CL (The World Counts, 2020) [66], rendering it an issue of global significance.

As protective mechanism, human rights equally concern all age groups, including children, who have the same basic human rights as adults. As children are considered to have unique needs and particular vulnerability (UNICEF, 2014) [67], additional rights apply to them as outlined in the Table A1 below.

UNICEF was the first international institution to grant children human rights independent of their parents through the UNCRC (1989) [19], marking a milestone in the fight for children (Radfar et al., 2018) [11]. However, although these overarching standards have been ratified by a number of economies, in particularly developing countries, lacking national legal prohibitions on child labour. Yet, if it does, limited resources result in the fact that the laws are not enforced (Amnesty International, 2016) [69]. Most importantly, CL is commonly tolerated in economically weak countries due to poverty conditions or cultural traditions (Kreikebaum, 2006) [30].

Table A1. Own table, based on ILAB (2018) [68].

\begin{tabular}{|c|c|}
\hline Convention & Content \\
\hline ILO C. 138, Minimum Age & $\begin{array}{l}\text { Defines the minimum working age as } 15 \\
\text { (adopted: 1973) }\end{array}$ \\
\hline ILO C. 182, Worst Forms of Child Labor & $\begin{array}{l}\text { Demanding the prohibition of any kind of } \\
\text { worst form of child labour (adopted: 1999) }\end{array}$ \\
\hline UN CRC & List of rights that children are entitled to (1989) \\
\hline $\begin{array}{l}\text { UN CRC Optional Protocol on } \\
\text { Armed Conflict }\end{array}$ & $\begin{array}{l}\text { Aims to protect children from military } \\
\text { recruitment (signed: } 2000 \text {, effective: } 2002 \text { ) }\end{array}$ \\
\hline $\begin{array}{l}\text { UN CRC Optional Protocol on the Sale } \\
\text { of Children, Child Prostitution and Child } \\
\text { Pornography }\end{array}$ & $\begin{array}{l}\text { Aims to protect children from sale, prostitution } \\
\text { and sexual abuse (signed: } 2000 \text {, effective: } 2002 \text { ) }\end{array}$ \\
\hline Palermo Protocol on Trafficking in Persons & $\begin{array}{l}\text { Three protocols aims at protecting children } \\
\text { and women against transnational organised } \\
\text { crime (signed: } 2000 \text { ) }\end{array}$ \\
\hline
\end{tabular}

